Archaeological Journal

\title{
The Late Mr. Burtt
}

E. V.

To cite this article: E. V. (1877) The Late Mr. Burtt, Archaeological Journal, 34:1, 90-92, DOI: 10.1080/00665983.1877.10851810

To link to this article: http://dx.doi.org/10.1080/00665983.1877.10851810

曲 Published online: 14 Jul 2014.

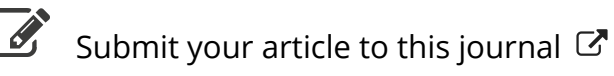

Q View related articles $\longleftarrow$ 


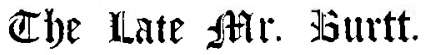

Among the many losses the Archrological Institute has been called of late to sustain there is not one which will have been more widely felt and more sincerely deplored than that of its late Honorary Secretary, Mr. Joseph Burtt. From his long connection with tho Institute, of which he was a valued member, and contributor to its proceedings for some years before he entered upon his official engagement as Secretary, few were more completely identified with our body, and none have ever laboured with greater diligence, and more zeal and intelligence for its welfare. Becoming Honorary Secretary in $1862, \mathrm{Mr}$. Burtt was for years, as has been truly said, "the prime mover and guiding spirit" in all the operations of the Society. The arrangements for the monthly meetings, and the difficult task of securing suitable memoirs for reading, and objects of interest for exhibition, devolved upon him, and like all that he undertook, however wearisome, was performed with untiring energy and never-failing good humour.

To Mr. Burtt also, after failure of health compelled the late Mr. Albert Way to retire from that duty, was year by ycar entrusted the responsible and anxious task of organizing and carrying out the Annual Congresses, and to his tact and courtesy, together with his clear head and calm business-like habits, the success of these gatherings has been mainly due. Few could have executed the preliminary duty of visiting the proposed place of meeting, stimulating the languid, encouraging the desponding, and awakening a general interest in the coming visit of the Institute, with so much delicacy and judgment as our lamented friend. The writer of this notice has on several occasions been associated with Mr. Burtt in the correspondence and other arrangements for the Annual Neeting, as well as in earrying these arrangements into effect, and he can truly say that he never knew one with whom his unfailing good sense and good nature made it more pleasant to work, and who impressed one more with the sense of earnest determination and hopeful courage. In the face of all difficulties, Mr. Burtt's resolve was that each meeting as it came should be a success; nor was he ever greatly disappointed.

During Mr. Albert Way's gradually failing health, the task of editing the Journal of the Institute was entrusted to Mr. Burtt, who became more and more responsible for it, until ultimately the whole burden devolved upon him. His untiring energy found a congenial exercise in bringing up the arrears of the publication, and making it increasingly worthy of the Society, whose organ it was. In this Mr. Burtt was ably seconded by several leading members of the 
Institute, and the growing excellence of the Journals during the two or three years preceding his decease was most marked. Another very laborions work undertaken by him, in addition to his other labours, was the preparation of the index to the volumes of the "Archæological Journal," from its commencement. He was engaged upon this when his fatal illness began. It is satisfactory to be able to state that our lamented friend's unfinished work has been taken up by the able hands of Sir John Maclean, and will, it is hoped, be before very long in the hands of the Subseribers. This Index will show how largely the Journal has been indebted to Mr. Burtt's pen. But his acknowledged contributions only show a small portion of the labour bestowed by him in working up the rough material furnished by others into a form suitable for appearance in its pages.

Mr. Burtt was also a contributor of archeological articles to the Gentleman's Mragazine and the Athencoum. A paper of his appeared in the "Archeologia Cantiana," vol. vi.

The second volume of the "Miscellany" published by the Camden Society contains "the Household Expenses of John of Brabart" (son of the Duke of Brabant, and husband of Margaret, daughter of Edward I) and "Thomas and Henry of Lancaster" (sons of the king's brother, Edmund Earl of Lancaster), in the year 1292-3, from the original roll in the Chapter House, from which place the Introduction is dated "Dec. 1852."

We have spoken of Mr. Burtt hitherto only in connection with the Archreological Institute, but it must not be forgotten that his archrological reputation was won in another field, before he became officially connected with our body. Born in 1818, he commenced his life-work when a lad of fourteen, under Sir Francis Palgrave in the Chapter House at Westminster. "Under that able and learned antiquary," to quote an appreciative notice that appeared shortly after his death in the Athenreum, "he served his apprenticeship, being chiefly employed on work connected with the Record Commission until the year 1840, when he was appointed to a clerkship in the New Record Establishment. He continued his labours for many years at the Chapter House, arranging and making inventories of the valuable collection of ancient records formerly stored in that depository. In August 1851 he was promoted to an assistant keepership of the second class, and was made a first class assistant keeper in June 1859. About this time he superintended the removal to the new Record Office, and the arrangement therein of the vast mass of documents which had been lying (many of them in a state of disorder) for centuries in the Old Chapter House." The calondaring of the Chancery Records of Durham was a task in which he was engaged for many years in addition to his other official duties.

Mr. Burtt had very few equals as a decipherer of ancient documents. The writer of this notice made his first personal acquaintance with Mr. Burtt in this character. He was examining some rolls of Isabella de Fortibus, connected with her possessions in the Isle of Wight, and was baffled by some medieval contractions. The document was shewn to some able palceographists belonging to the office in vain, and the cry arose, "Send for Burtt, he'll make it uut." Mr. Burtt's attendance rias requested, and without a moment's hesitation the words were read off. On another occasion the writer remembers taking to Mr. Burtt a dirty crumpled piece of parchment covered with writing by an 
illiterate hand, in pale ink, with the remark "Here's something that I think will baffle you." But the apparently illegible document was speedily deciphered, almost as easily as if it had been written in a clerkly hand.

Mr. Burtt was always most ready to devote his archoological and palreographical knowledge to the servico of others. For some years ho was employed in his private capacity by the Dean and Chapter of Westminster in examining and describing the muniments connected with that ancient monastic foundation. He also performed the same services to a minor extent for the Dean and Chapter of Lincoln Cathedral. Some of the interesting historical documents discovered by him in this latter collection have been printed and illustrated in the pages of this Journal.

Floriculture was Mrr. Burtt's favourite recreation. Both at Brixton, and afterwards at Tulse Hill, he was accustomed to devote his mornings and evenings to his garden with great success. Chrysanthemums were his especial hobby, and he took great pride in the varied hues and perfect forms of his favourites, which ho tended and sheltered with affectionate care.

As a friend and colleague Mr. Burtt secured the respect and affection of all with whom he was connected. His well-stored mind, his genial character, his forgetfulness of self, and readiness to oblige, endeared him to all who knew him, who feel that his premature decease has left a gap in the circle of the friends that it will be impossible ever to fill up. The loss to the Archacological Institute of one who had its interests so zealously at heart, and who laboured so untiringly and intelligently for their promotion, is incalculable; though happily not so entirely irreparable as that sustained by his widow and large family.

E. T. 